\title{
THE ROLE OF SOLID WASTE MANAGEMENT SYSTEM IN INCREASE OF SECURITY BY POWER RESOURCES
}

\author{
Vadim Chekalin \\ Maria Lioubarskaya \\ St Petersburg State University of Engineering and Economics, Russia
}

\begin{abstract}
In modern conditions questions of efficient management of power resources get very actual meaning. The urgency of these problems is caused by many reasons, including:

- Limitedness of the natural resources used for manufacture of energy (oil, gas, coal);

- Increasing of expenses at extraction of natural resources and their delivery to objects of energy manufacturing in connection with development of deposits in more remote places;

- A high level of environmental contamination at use of traditional energy sources.
\end{abstract}

Therefore usage of nonconventional ecologically pure energy sources can give us a good opportunity to increase of security by power resources. As such sources we could use, for example, various types of waste: agricultural, industrial and also household solid waste.

These types of waste now are available in sufficient quantity in each country and their source never will run out. Besides in Russia acutely there is a problem of household solid waste management, the volumes which one rise with each year, and the adequate ways of their utilization miss. Thus usage of a household solid waste as a nonconventional ecologically pure energy source allows simultaneously to decide two problems: to increase security by power resources of the Russian regions and to find an effective way of household solid waste utilization.

\section{KEYWORDS}

Power resources; Nonconventional ecologically pure energy sources; Solid waste management system; Household solid waste

\section{INTRODUCTION}

Recently foreign countries give big attention to researches on use of nonconventional ecologically pure energy sources. For example, inhabitants of the Great Britain had an opportunity to prove the adherence to preservation of an environment owing to the grants given within the limits of the governmental program of use of renewed energy sources [1]. For realization of the program «Pure heavens» it is allocated 10 million pounds sterling. Minister of power of the Great Britain Bryan Wilson has informed, that the project «Pure heavens» is a part of the governmental strategy and is directed on attraction of British people to participation in the program, which purpose - reduction of emissions of carbonic acid gas. Many houses in the Great Britain are badly warmed, because of what there is a loss of heat, 
and it, in turn, raises cost of heating and leads to greater pollution of an atmosphere. That is why campaign «Pure heavens» will promote also to economy of energy. As it is marked in reports of the Govemment of the Great Britain, real transition to "green power» will begin only when people will see opportunities for realization of such projects in local conditions.

Besides questions of environmental contamination stimulus to search of ways of nonconventional energy sources using is the high degree of exhaustion of natural resources. In opinion of scientists, the Mankind demands from the Earth more, than our planet can give it. The information given by the head of group of the international experts at the National Academy of sciences of the USA, testifies that in the last the Mankind consumes some years on $20 \%$ more than a minimum reproduced by the nature. The purpose of research of scientists was calculation of conformity of inquiries of mankind to reproduced resources of the Earth. They have come to conclusion, that natural resources can be settled by Mankind much earlier, rather than it was expected.

Russia has a lot of problems in questions of energy supplying but it is just going to take the way of using nonconventional ecologically pure energy sources.

\section{SOLID WASTE AND SECURITY BY POWER RESOURSES}

Therefore it is a high time to turn the look on a reuse of waste of production and consumption. Sources of a biomass are various: these are agricultural waste, wood waste, waste of food, textile and microbiological industry, and also household solid waste. Effectively organized solid waste management system will allow to solve a problem of an exhaustion of natural resources. Billions tons of the accumulated solid waste can become raw material for processing and reception of weight of substances necessary for Mankind. In fact waste are simply useful materials which we yet have not learned to use.

In large cities of Russia most part of municipal solid waste is going to official landfills and non-authorized dumps now. The total area of such sites in the Russian Federation is about 15 thousand hectares. Unfortunately in our country works on industrial development of manufacturing biogas and energy from hydrocarbonic waste at landfills are conducted extremely unsatisfactorily. Small operating experience of ranges on landfills with recycling biogas is available in the Moscow region with use of the equipment from Holland. The results received at it testify to the big perspectivity of works on collecting and utilization of biogas from hydrocarbonic waste. Non-use of biogas for reception of energy besides a missed economic gain leads to necessity of application for these purposes of not renewed hydrocarbonic fuel, and also to environmental contamination.

Modern landfills represent complex engineering constructions on which sorting of solid waste is made. On occasion there recycling of the most valuable secondary resources containing in waste is implemented. The biogas formed at anaerobic decomposition of organic waste concerns to such utilized resources also. The structure of biogas which concerns to renewed energy sources, includes $50-60 \%$ of methane. Ability of heat extracting of biogas is rather high, that does its collecting, transportation and industrial utilization economically expedient.

Considering, that about 1 hectares of range within a year it is possible to collect nearby 1 million cubic meters of biogas, its manufacture in the country could make impressive figure 15 billion cubic meters a year. At total amount of consumption of natural gas in 400-450 
billion cubic meters a year, biogas could be a source of economy of natural resources and, that the most important, - a renewed energy source.

Also it is necessary to consider and the major ecological effect from collecting the biogas allocated on solid waste landfills since methane at 7-10 time is more dangerous some carbonic acid gas from the point of view of influence on development of a hotbed effect. Besides it could make the explosion and fire, is toxic and creates adverse ecological conditions for inhabitants of nearby areas to solid waste landfills, and also for the personnel serving it. Use of solid waste landfills as operated chemical reactors for reception of a renewed energy source allows to increase also service life of landfill since at adjustable collecting biogas there is a uniform mineralization of a biomass, and reduction of thickness of a landfill's body occurs without formation of emptiness. At absence of management formation and collecting allocated at decomposition of hydrocarbonic waste of biogas occurs destruction of a body of solid waste landfill owing to dump of pressure of gas inside of it.

Generating of biogas is influenced with age of landfill, structure, density of stacking, temperature and humidity of waste, and also thickness of a landfill's body and ways of operation of landfill.

In the most simple case biogas collects and goes on the pipeline to the consumer as fuel instead of other energy sources. As such consumers can be the enterprises making building materials and using biogas for roasting a brick or a ceramic tile. Departing smoke gases can be used for reception pair and hot water for agricultural and household needs.

Other simple variant of use of biogas is burning in the certain installations for reception of an electricity. It can be gas engines with spark ignition or gas turbines. Gas engines allow to create low-power installations. Application of duple gas engines without inlet and final valves is the most expedient.

Gas turbines are effective at capacity more than $2 \mathrm{MWt}$. The efficiency of gas turbines makes $32 \%$. More expensive is reception of high-quality gas. It demands removal of not methane components that is reached by chemical or physical methods.

Now in the USA, the Great Britain, Germany, Spain, India, China are in commercial operation of tens thousand installations on reception of biogas from household solid waste.

Many European countries have far promoted in questions of household solid waste using for reception of energy already enough. The representative of municipality of city of Amsterdam has declared that since 1 st of January of 2001 the new supplier of the electric power for city needs is the service on processing dust which has started transformation of heat received at combustion of city waste, to an electricity [2]. Annual capacity of installation allows to process 800000 tons of the dust collected in Amsterdam and its vicinities. According to the corresponding contract signed between representatives of municipality and a urban service on processing of dust, rather cheap electric power will act, basically, for needs of a city transport facilities.

Austrian firm «Biogas» has developed an original way of reception of the electric power from food waste [3]. The firm collects daily 12 tons of food waste from 850 restaurants and private houses of district Kirshdorf. At processing waste methane which are actuated with the 
mechanism developing the electric power is allocated. The invention of firm «Biogas» has delighted inhabitants of Kirshdorf, and especially local municipal services.

Gasoline and diesel fuel in the countries of the European Union will be gradually replaced with bio fuel. Such recommendation contains in the instruction approved at session of Euro Parliament in Strasbourg [4]. The document orders to replace to $20052 \%$ of consumed gasoline and diesel fuel with fuel of a phytogenesis. By 2010 the share of bio fuel should increase up to $10 \%$. As experts mark, bio fuel (for example, ethanol) which is made on the basis of agricultural crops, will allow to reduce substantially pollution of an atmosphere by the gases rendering fatal «hotbed effect». At use of bio fuel in an atmosphere it is thrown out on $40-80 \%$ of less gases, than from usual gasoline. Use of bio fuel has for the European Union important value and by way of decrease in power dependence on other countries.

Not only the Europe goes on a way of use of household solid waste for reception of energy. In Japan the decision on reception of energy from food and household waste too is accepted [5]. The government of Japan has promulgated the scale plan of reception of fuel for cars and power stations from waste. The project is called to reduce dependence of the country on export of power resources and to help with struggle against pollution of an atmosphere. «Fuel from a biomass»" receive by processing organic waste, first of all collateral agricultural production and household waste. At combustion it allocates much less than harmfui substances, than, for example, oil raw material.

The countries of former Soviet Union recently also have attended to questions of reception of energy from nonconventional sources. In Belarus the opportunity of construction by German businessmen of a municipal solid waste processing plant with reception of energy is considered [6]. As it is supposed, such plant can be constructed in Minsk. It is a question of the investment project in 35 million euro. By estimations of experts, the potential energy concluded in solid household waste, formed in territory of Belarus, is equivalent 470 thousand tons of conditional fuel. At their bioprocessing with the purpose of reception of gas efficiency makes no more than $20-25 \%$ that is equivalent $100-120$ thousand tons of conditional fuel. In Belarus annually collects nearby 2,4 million tons of household solid waste which basically go on dumps. Only in regional cities annual processing of household solid waste in gas would allow to receive nearby 50 thousand tons of conditional fuel of biogas, and in Minsk - up to 30 thousand tons of conditional fuel.

Ukraine too cannot provide completely itself with energy carriers and is compelled to import their most part that is important clause of import and a brake of development of a national economy. For Ukraine development of biotechnologies today have paramount value [7]. Biotechnologies help to form convenient for recycling energy of a renewed vegetative biomass or to waste of cattle-breeding farms, and also household solid waste. Various forms of energy of a biomass can be used for generating the electric power, and also as fuel for transport. There are some kinds of transport fuel which can be received from a biomass: biogas (mainly methane), a biodiesel engine and bioethanol. It is considered, what exactly fuel ethanol has the greatest potential, considering inexhaustible sources of its reception. They can be grassy plants and wood, waste of an agriculture and wood industries, and also household solid waste. Ukraine has ample opportunities of industrial production of fuel ethanol as makes many products of field husbandry. A plenty of agricultural waste - straw, corn, a peel of a sunflower annually collects. Besides the significant amount of household solid waste, basically consisting of pulp is collected. 
Maintenance of profitability of manufacture of fuel ethanol demands reduction in price of this product which basic way can be replacement of raw material for its manufacture. Replacement of raw material consists that instead of grain of cereals for transformation into ethanol the biomass of the whole plants both grassy will be used, and trees, including waste of an agriculture, wood industries and even household solid waste. Use of such nonconventional materials does a raw-material base for reception of fuel ethanol practically inexhaustible. Calculations testify: use for manufacture of fuel ethanol only waste of an agriculture, wood industries and household solid waste would allow the USA to replace the industries ethanol of $40 \%$ of gasoline.

In Russia also there is a plenty of raw material which can be used as nonconventional sources of reception of energy. For example, the potential volume of wood waste in Leningrad region makes 6 million cubic meters in a year [8]. Use of such fuel is perspective both in ecological and economic ways - expenses for purchase of imported fuel decrease.

Recently the big distribution was received with scientific development on problems of realization of an energy potential of industrial and municipal waste with use of technology of gasification. Development of new highly effective technology of processing of a various types of the waste containing combustible materials, in a mode of gasification with the subsequent recycling received energy carriers has wide prospects. Perspectivity of new technology is defined by an opportunity to solve environmental problems connected with accumulation and storage of the solid waste containing combustible materials, and ecologically safe manufacture of energy carriers and other commodity output. Development of this technology in Russia where the energy potential of waste accumulated during year makes nearby 92 million tons of conditional fuel is especially actual. In comparison with size of consumption of power resources in Russia in 1990, equal 1270 million tons of conditional fuel it makes more than $7 \%$ or about $18 \%$ consumed for manufacture of the electric power of fuel for boiler-houses. The significant volume of researches on the lab ware of numerous types of waste, including, household solid waste, automobile tires, waste of the industrial enterprises, including plastic, gum products, waste of mineral oil, waste of wood and products of its processing is lead. It is established, in particular, that in offered modes of gasification processing of solid household and wood waste with humidity up to $70 \%$ is possible.

During several last decades to creation of system of efficient control by power resources in Russia it was not given due attention. It is a lot of years of the price for fuel were it is artificial are underestimated. In the former Soviet Union practically there were no financial stimulus for economy of fuel. It is possible even to tell, that the economic force in development of power really did not exist. Now the prices for fuel in comparison with what were in the USSR, steel in some times above.

Since 1973 the most part of the European countries has developed special strategy of development of power. One of prominent aspects of last was that have entitled regions to develop power within the limits of the competence. As a result of carrying out of such policy during a life it has appeared, that it is favorable to farmer to carry straw on power station, it is favorable to sort waste, receiving thus valuable raw material and gratuitous energy, etc. At us the similar policy in the field of power is absent. An energy potential such sources as waste of wood industries, peat, household solid waste practically is not demanded. In fact today still favorably simply it is more to open the crane on the pipeline of natural gas or black oil. 
As one of factors of increase of security power resources it is necessary to consider use of various kinds of solid waste. The set testifies to it resulted above proofs. For efficient control power resources along with strategic planning in sphere of power it is expedient to provide interrelation of this strategy with strategy of development of system of the reference with firm waste. The power policy in our country should be under construction also so that it was impossible to pass by that circumstance when energy in a literal sense rolls under legs.

\section{THE WAYS OF PERFECTING OF SOLID WASTE MANAGEMENT SYSTEM}

To play the important role in maintenance of security by power resources the solid waste management system needs to be perfected. The mining and implementation of proper policy of solid waste management demands considerable costs. And, costs these will wear both capital and current nature. The looking up of sources of means for implementation of the consumptions is a separate subject. Within the framework of this activity we shall consider only directions of their usage. We suggest a complex of measures which could help us to increase security by power resources through perfecting solid waste management system. Among them we can secure:

- Perfecting normative - legal base of solid waste management at all levels (local, regional, federal, international), legislative fastening of priority of household solid waste utilization for effecting energy;

- Realization of marketing researches of an existing situation in the field of solid waste management in each region, Looking up of ways of household solid waste utilization for energy production;

- Creation of economical and other stimulants for usage of non-polluting ecologically pure energy sources, including household solid waste;

- Engaging of credit and other means for development of an orb of solid waste recycling with energy production;

- Detection of producers of solid waste, which can be used as energy sources, creation of the conforming databases;

- Detection of potential customers of non-polluting ecologically pure energy, creation of the conforming databases;

- Creation of intercouplings between the suppliers and customers of non-polluting ecologically pure energy sources, formation of information flows;

- Progression of technologies of energy production from non-polluting ecologically pure energy sources;

- Perfecting a household solid waste collecting system, intrusion of principles of the separate collecting, creation of a network of points of secondary raw materials collecting;

- Perfiecting a system of household solid waste processing and landfilling to increase the volume of household solid waste using for energy production;

- Definition of measures on development of an orb of energy generation from non-polluting sources, including household solid waste, realization of campaign on progression of the energy produced from non-polluting ecologically pure sources;

- Realization of psychologic opening-up of all groups of the participants of the process of solid waste recycling with energy production;

- Realization of training and retraining of the specialists for activity with technologies of energy production from non-polluting ecologically pure sources, including household solid waste. 
All this measures of perfecting of solid waste management system should be implemented especially in regions of Russia because the problems of security by power recourses and utilization of household solid waste there get a very actual meaning.

\section{CONCLUSIONS}

As one of factors of increase of security by power resources it is necessary to consider use of various types of solid waste. For efficient management of power resources it is expedient to provide interrelation of development strategy in this sphere with strategy of development of solid waste management system. On the basis of the planned strategic directions the concrete program of the actions should be prepared.

Mutual coordination of these strategies will allow to solve the following problems with solid waste and energy:

1. To involve for maintenance with power resources nonconventional sources, such as household solid waste, wood waste, agricultural waste, etc.

2. To improve an environment due to use more ecologically safe sources of energy production and reduction of not renewed natural resources using.

3. To receive additional incomes of involving solid waste in manufacturing process, using of secondary resources and reducing of landfills' areas.

\section{REFERENCES}

[1] The Great Britain: the "green» grants for houses. [Electronic resource] www.est.co.uk

[2] Amsterdam: waste - new power source for urban needs. [Electronic resource] www.news.battery.ru

[3] Austria: how to get the electric power from waste. [Electronic resource] www.news.battery.ru

[4] Strasbourg: countries European Union pass from gasoline on biocombustible. [Electronic resource] www.news.battery.ru

[5] Tokyo: Japan passes on fuel from waste. [Electronic resource] www.news.battery.ru

[6] The German businessmen plan to construct in Minsk a plant on processing. [Electronic resource] www. unipak.ru

[7] Power system - source of financial resources. [Electronic resource] www.zerkalonedeli.com

[8] The potential volume of arboreal waste in the Leningrad region makes of 6 millions cubic meters annually. [Electronic resource] www.regions.ru 